\title{
GEOGRAPHICAL FEATURES OF POVERTY AND FORMATION OF MIDDLE CLASS IN UKRAINE
}

\author{
Julia PEREGUDA \\ Taras Shevchenko National University of Kyiv, Ukraine \\ Julia_pereguda@ukr.net
}

\begin{abstract}
Analysis of social and geographic aspects of the study of the middle class in Ukraine and government policy on poverty reduction is very important at current stage of social development. Although the problem of poverty in Ukraine gained official recognition after the approval of the Poverty Reduction Strategy by the Decree of President of Ukraine dated 15 August 2001 p. \# $637 / 2001$, significant results could not be reached. The heterogeneity of poverty and problems of the middle class depends on a number of factors resulting from regional conditions. Poverty as a socio-economic phenomenon is directly related to both the level of economic development and inequality in access to tangible and intangible benefits. Like poverty, the middle class is present in every modern society, but the difference lies in the degree of its uniformity, stability, scale, and role in society. The main features of the middle class are: the level of material wealth and consumption, education and professional qualification status, economic and social motivation, method and way of life, the ability to self-organize. The study bases on statistical information by Ukrainian regions related to assessment of relative poverty and poverty depth. Strong middle class cannot form while poverty increases. Therefore, the state policy targeting poverty in Ukraine should imply a certain system of measures aimed on the increase of GDP per capita and considered regional policy to eradicate regional poverty and to develop mechanisms of encouragement new jobs creating etc.

Therefore, the problem of poverty reduction and formation of the middle class needs to be addressed by implementing strategic directions and improving regional policy. The formation of future strong middle class should associate with the prospects of poverty reduction programs in Ukraine. TO develop a powerful middle class in Ukraine, this process should be considered as an important component of the state social and economic policy.
\end{abstract}

Key words: middle class, poor, poverty, absolute poverty, relative poverty line, subjective poverty

UDC: 911.3

\section{ГЕОГРАФІЧНІ ОСОБЛИВОСТІ БІДНОСТІ ТА ФОРМУВАННЯ СЕРЕДНЬОГО КЛАСУ В УКРАЇНІ}

\author{
ЮЛія ПЕРЕГУДА \\ Київський начіональний університет імені Тараса Шевченка, Україна \\ Julia_pereguda@ukr.net
}

\begin{abstract}
Анотація: У статті розглядаються суспільно-географічні погляди на розвиток середнього класу в Україні. Розкрито суть понять «бідність» та «середній клас». Визначено суспільно-географічні аспекти дослідження середнього класу та напрямки державної політики щодо скорочення масштабів бідності в Україні. Обґрунтовується необхідність здійснення державою заходів для створення відповідної нормативно-правової бази з питань подолання бідності. Формування майбутнього середнього класу необхідно пов'язувати з перспективами впровадження програм подолання бідності в Україні.

Ключові слова: середній клас, бідність, подолання бідності, абсолютна межа бідності, відносна межа бідності, суб'єктивна бідність.
\end{abstract}

удк: 911.3

Вступ. Постановка проблеми. Становлення середнього класу зумовлено економічними, політичними та причинами соціального характеру. Світовий досвід демонструє, що середній клас ставиться в залежність з процесами, пов'язаними з економічним зростанням, підвищенням рівня життя населення, зменшенням розриву між доходами населення, тобто поляризації суспільства. Однією 3 проблем, зумовлених трансформаційними процесами в економіці України, є низький рівень життя населення. Отже, середній клас має бути частиною економіки та складовою основою політики подолання бідності в Україні.

Аналіз досліджень та публікацій. Концепція середнього класу в сучасному розумінні має свої історичні передумови, закономірності виникнення

(C) Ю. Перегуда під час еволюції соціально-економічного устрою суспільства. Проблемі середнього класу приділяли увагу ще Аристотель, А. Сен-Сімон, К. Маркс, М. Вебер, А. Сміт. У наш час зростає практичне значення вивчення регіональних аспектів походження та поширення бідності. Зокрема, особливу увагу приділено регіональним аспектам бідності в роботах Е. М. Лібанової, Б. Г. Тукумцева, О. О. Разумова, Г. І. Чепурко, Л. М. Черенько, П. І. Шевчука, М. О. Ягодкіної. Різноманітними аспектами цього питання займаються такі науковці, як О. Александрова, В. Савчук, С. Головаха, Ю. Зайцева, С. Макеєв, Л. Шангіна, а також науковці суспільно-географічного напряму М. О. Барановський, Н. I. Мезенцева, I. Г. Мельник.

Разом $з$ тим, суспільно-географічні дослідження середнього класу й досі $є$ мало численними. Однак 
Критерії приналежності до середнього класу

*Складено за матеріалами Інституту демографї та соціальних досліджень НАН Украӥни [8]

\begin{tabular}{|c|c|}
\hline Матеріальний добробут & $\begin{array}{l}\text { поточний дохід, рухоме і нерухоме майно,заощадження } \\
\text { (грошові внески,облігації і іниі иінні папери) }\end{array}$ \\
\hline Володіння капіталом & $\begin{array}{l}\text { підприємства,фірми з найманою робочою силою,майно } \\
\text { для індивідуальной трудової діяльності. }\end{array}$ \\
\hline $\begin{array}{c}\text { Професійно-посадовий } \\
\text { статус }\end{array}$ & $\begin{array}{l}\text { освіта,кваліфікауія,науковий ступінь, рівень складності } \\
\text { професійної діяльності. }\end{array}$ \\
\hline Політичний статус & $\begin{array}{l}\text { ступінь впливу на ухвалення рімень органами державної } \\
\text { влади різних рівнів і органами місуевого самоврядування. }\end{array}$ \\
\hline $\begin{array}{c}\text { Потенціал соціальної } \\
\text { мобі.льності }\end{array}$ & $\begin{array}{l}\text { вірогідність підеищення соуіального статусу в } \\
\text { суспільстеі. }\end{array}$ \\
\hline $\begin{array}{c}\text { Статусність способу і якості } \\
\text { життя }\end{array}$ & $\begin{array}{l}\text { якість поточного споживання, якість середовица } \\
\text { проживання,якість дозвілля. }\end{array}$ \\
\hline $\begin{array}{l}\text { Самоідентифікація себе із } \\
\text { середнім класом. }\end{array}$ & $\begin{array}{l}\text { власна думка про приналежність до середнього } \\
\text { класу,та неможливість віднесення себе до бідних. }\end{array}$ \\
\hline
\end{tabular}

дослідження суспільно-географічних аспектів середнього класу та подолання бідності становить особливе значення для регіональної політики в Україні щодо підвищення рівня життя населення.

Формулювання цілей статті. Постановка завдання. Населення країни є різним за потребами та можливостями їх задоволення. Однією 3 найгостріших соціально-економічних проблем, зумовлених трансформаційними перетвореннями в економіці України, є низький рівень життя населення. Це дослідження є актуальним, оскільки неможливість формування середнього класу, $є$ проблемою яка спостерігається в розрізі регіонів, і зумовлена як економічними, соціально-демографічними та природними чинниками. В Україні відбувається розшарування населення, а розрив між багатими та бідними стає значним, тому без середнього класу опори суспільства, побудувати соціально-економічну країну буде неможливо.

Тому, метою даної статті $\epsilon$ аналіз суспільногеографічних аспектів дослідження середнього класу в Україні та напрямів державної політики щодо скорочення масштабів бідності. Головними завданнями даного дослідження є аналіз поширення бідності в регіонах України, визначення географічних аспектів дослідження бідності та обгрунтування можливості для формування середнього класу, а також пошук стратегічних напрямів для розвитку середнього класу в Україні.

Виклад основного матеріалу дослідження. Неоднорідність поширення бідності та проблем формування середнього класу залежить від впливу низки факторів, що $є$ результатом умов розвитку певної території. Середній клас - це сукупність соціальних верств населення, які отримують рівень доходів, що дає змогу їм жити в умовах достатку, які займають в стратифікаційній системі суспільства проміжне положення між нижчим класом (бідними) i вищим класом (багатими), представники яких мають високий кваліфікаційно-освітній рівень, відчувають престижність власного становища в суспільстві та відіграють важливу роль у підтримці стабільності в країні [8, с. 170]. Бідність, як соціально-економічне явище безпосередньо пов'язана як 3 рівнем економічного розвитку, так $з$ нерівністю у доступі до матеріальних та нематеріальних благ. Офіційне визначення поняття бідності в Україні звучить так: «бідність - це неможливість унаслідок нестачі коштів підтримувати спосіб життя, притаманний конкретному суспільству в конкретний період часу» [14]. Середній клас - як і бідність - наявний у кожному сучасному суспільстві, але різниця полягає в ступенях його однорідності, стабільності, масштабах та ролі в суспільстві [4, с. 47]. Різного роду критерії приналежності до середнього класу, відрізняються залежно від змісту дослідження та країни для якої критерії розробляються (табл.1). Вимогою, яка висувається до таких критеріїв, є їхня взаємозалежність за змістом [8, с. 170].

Суспільно-географічне дослідження бідності має спиратися на національні підходи щодо iіi вимірювання, що $є$ проблемою методологічного характеру. В Україні, як і в міжнародній практиці, усі підходи до кількісної оцінки бідності грунтуються на трьох основних концепціях, до яких належать:

- абсолютна, згідно якої до бідних належать 
Рівень бідності в 2011- 2013 рр. за регіонами України, \%

\begin{tabular}{|c|c|c|c|c|c|c|}
\hline & \multicolumn{3}{|c|}{ За відносним критерісм } & \multicolumn{3}{|c|}{$\begin{array}{c}\text { За абсолютним критерісм } \\
\text { (за витратами) }\end{array}$} \\
\hline & 2011 p. & $2012 \mathrm{p}$. & 2013 p. & $2011 \mathrm{p}$. & $2012 \mathrm{p}$. & 2013 p. \\
\hline АР Крим & 25,0 & 26,7 & 25,5 & 16,6 & 22,5 & 22,9 \\
\hline Вінницька & 22,4 & 20,7 & 24,7 & 13,9 & 18,2 & 23,5 \\
\hline Волинська & 32,3 & 37,3 & 35,3 & 14,3 & 29,3 & 30,6 \\
\hline Дніпропетровська & 28,8 & 26,7 & 27,4 & 20,9 & 22,8 & 23,5 \\
\hline Донецька & 21,9 & 21,0 & 25,3 & 13,3 & 18,2 & 21,9 \\
\hline Житомирська & 37,5 & 31,6 & 38,7 & 29,0 & 26,8 & 33,8 \\
\hline Закарпатська & 31,5 & 26,4 & 21,6 & 24,5 & 21,0 & 19,2 \\
\hline Запорізыка & 15,6 & 15,1 & 15,6 & 8,7 & 12,1 & 13,6 \\
\hline Івано-Франківська & 25,8 & 31,1 & 26,4 & 10,3 & 24,6 & 21,1 \\
\hline Київська (без м.Кисва) & 22,6 & 23,9 & 23,5 & 9,6 & 18,2 & 16,8 \\
\hline Кіровоградська & 37,8 & 44,6 & 32,2 & 27,5 & 38,3 & 27,2 \\
\hline Луганська & 29,2 & 21,6 & 25,9 & 17,6 & 18,3 & 20,1 \\
\hline Львівська & 33,1 & 30,5 & 29,8 & 24,6 & 25,9 & 24,5 \\
\hline Миколаївська & 19,1 & 17,1 & 18,6 & 11,0 & 14,7 & 16,9 \\
\hline Одеська & 26,7 & 35,0 & 33,2 & 20,7 & 27,7 & 30,2 \\
\hline Полтавська & 19,5 & 32,0 & 23,8 & 10,9 & 28,8 & 20,7 \\
\hline Рівненська & 39,2 & 45,6 & 46,1 & 24,0 & 35,6 & 40,5 \\
\hline Сумська & 22,5 & 37,1 & 36,0 & 17,5 & 30,8 & 32,8 \\
\hline Тернопільська & 35,0 & 44,0 & 43,3 & 27,9 & 37,3 & 36,5 \\
\hline Харківська & 15,5 & 18,1 & 17,3 & 7,9 & 11,7 & 13,4 \\
\hline Херсонська & 23,8 & 26,3 & 30,3 & 16,2 & 20,9 & 27,6 \\
\hline Хмельницька & 36,0 & 31,8 & 30,2 & 27,1 & 28,9 & 24,5 \\
\hline Черкаська & 14,3 & 20,8 & 15,6 & 11,7 & 20,0 & 13,0 \\
\hline Чернівецька & 24,8 & 35,9 & 19,1 & 16,9 & 32,7 & 18,6 \\
\hline Чернігівська & 23,6 & 21,7 & 17,9 & 17,6 & 18,5 & 16,0 \\
\hline м. Київ & 6,4 & 9,1 & 6,4 & 4,2 & 7,6 & 4,9 \\
\hline Україна & 24,5 & 26,1 & 25,4 & 16,2 & 21,7 & 21,7 \\
\hline
\end{tabular}

*3а даними Державної служби статистики України [13]

Рівень бідності населення Украӥни в 2013 році у розрізі типу населеного пункту, \%*

\begin{tabular}{|c|c|}
\hline Тип населеного пункту & Рівень бідності ,\% \\
\hline Велике місто & 17,5 \\
\hline Мале місто & 28,9 \\
\hline Село & 32,1 \\
\hline Київ & 7,5 \\
\hline Україна & 24,3 \\
\hline
\end{tabular}

*Розраховано співробітниками Інституту демографії та соціальних досліджень ім. М. В. Птухи НАН України за даними обстежень умов життя домогосподарств. 
особи, що мають менше, ніж об'єктивно встановлений абсолютний мінімум ресурсів, необхідних для задоволення основних соціально-культурних потреб на мінімальному рівні [2, с. 23];

- відносна, за якою людина або сім'я вважається бідною в тому випадку, якщо кошти, які вони мають, не дозволяють їм вести спосіб життя, притаманний суспільству, у якому вони живуть [9];

- суб'єктивна, згідно якої до категорії бідних належать особи, які відчувають, що не мають достатніх доходів або наявних ресурсів, щоб жити, за їх думкою, на достатньому рівні життя, властивого для певного суспільства [2, с. 25].

Сьогодні, незважаючи на незначне підвищення показників рівня життя і загальне поліпшення ситуації 3 бідністю, зберігається залежність між рівнем матеріального добробуту родини та іï соціальнодемографічними та соціально-економічними характеристиками[8].Згідносоціологічнихдосліджень проведених Українським центром економічних i політичних досліджень імені Олександра Разумкова у 2014 році, серед респондентів старше 18 років у всіх областях України, Києві та АР Крим за вибіркою, за головними соціально-демографічними показниками, показує, що 33,6\% населення України відносять себе до представників середнього класу. У країнах Європи цей показник становить 55-70\%, в США понад 87\% [5]. Але згідно майнових показників до середнього класу відносяться тільки 8,9\% українців. Виходячи зі статистики, середнього класу в Україні дуже мало, і ще не сформовано достатніх умов для розвитку численного середнього класу через соціально-економічні та політичні перетворення, які відбуваються в країні.

Проблема майнового розшарування населення набуває соціальної важливості у зв'язку з проблемою бідності частини населення України. Упродовж останніх років в Українібулирозроблені тавпроваджені певні заходи щодо подолання та попередження бідності населення [2]. Варто зазначити, що в регіональному розрізі 2013 році в Україні найвищий рівень бідності за відносним критерієм, є Рівненська та Тернопільська області - рівень бідності відповідно становить $46,1 \%$ та $43,3 \%$, що в 1,7 - 1,8 рази вище за середнє по країні значення. Надвисокий рівень бідності також зафіксований у Житомирській $(38,7 \%)$, Сумській (36,0\%) та Волинській (35,3\%) областях. Суттєво вищий за середньоукраїнський рівень бідності спостерігається у Одеській $(33,2 \%)$ та Кіровоградській $(32,2 \%)$ областях. Окремої уваги, заслуговує м. Київ, у якому рівень бідності традиційно залишається найнижчим серед усіх регіонів, де значення показника відносної бідності становило 6,4\%, що майже у 4 рази нижче за середнє по країні. Відносно низькі значення рівня бідності характерні для Черкаської (15,6\%), Запорізької(15,6\%), Харківської(17,3\%), Чернігівської $(17,9 \%)$, Миколаївської $(18,6 \%)$ та Чернівецької (19,1\%) областей. Рівень бідності в 2011-2013 рр. по регіонах України представлений у таблиці № 2 [13] Таким чином, географія бідності сьогодні не має чітко окреслених рис, оскільки до полярних за показниками бідності груп регіонів потрапляють області з різних географічних зон (табл.2).

Важливою характеристикою ступеня соціальної нерівностірегіонів Україниєрегіональнадиференціація рівнів бідності. Хоча бідність визначається за різними критеріями i досліджується за різними формами, найбільш важливими показниками є відносна бідність, яка визначається за рівнем витрат, що не перевищує $75 \%$ середнього по країні в розрахунку на умовного дорослого, та абсолютна бідність відповідно до законодавчо визначеного прожиткового мінімуму. Рівень бідності населення України у розрізі типів населених пунктів представлений у таблиці №3.

Таким чином, спостерігається відчутна нерівність населення України рівня бідності залежно від типу місцевостіпроживання, яка характеризується суттєвою різницею між великими містами та малими містами й селами. Середній клас неподільно пов'язаний з рівнем бідності в країні і чим нижчий рівень бідності, тим потужніший середній клас. Ситуація з бідністю буде гіршою за умови врахування немонетарних критеріїв бідності, таких як відсутність інфраструктури, обмежений доступ до закладів системи охорони здоров'я та освіти. Розподіл населення України за місцем проживання середнього класу відрізняються залежно від типу проживання населення (рис.1).

Отже, характеристика бідності в регіонах України показує, що відповідно до загальноукраїнських тенденцій у більшості регіонів у 2013 році відбулося зниження рівня бідності за середньоукраїнською межею, але середній клас не може повноцінно функціонувати в регіонах, де бідність становить загрозу. Узагальнюючи всі показники можна визначити стратегію комплексної програми подолання бідності й створення умов для середнього класу (табл. 4).

Головною передумовою формування середнього класу є зменшення рівня бідності та пристосування домогосподарств до ринкових відносин, усвідомлення необхідності розраховувати на власні можливості при зменшенні соціальних зобов'язань 3 боку держави перед громадянами, також залежить від удосконалення структури доходів і від змін споживчого ринку. Негативні процеси в економіці, які показують недосконалу діяльність держави у сфері зменшення нерівності, відсутність ефективних реформ та визначення пріоритетів на коротко-, середньо- i довгострокову перспективу(рис.2). Бідність в Україні пов'язана 3 соціально-економічними процесами, що створюють умови для формування структурної бідності. Головні цілі 3 подолання бідності мають бути закріплені на законодавчому рівні з врахуванням досвіду європейських країн та створювати нові економічних умов для формування середнього класу.

Висновки і перспективи подалыших розвідок. За результатами дослідження можна зробити наступні висновки. Становлення середнього класу варто пов'язувати 3 програми подолання бідності в Україні. В країні спостерігаються такі негативні явища, як низький рівень доходів населення, диспропорція в їх структурі, висока регіональна диференціація доходів населення в регіонах. На жаль, офіційна статистика доходів населення та витрат в Україні не відтворює в повній мірі реальну картину бідності. Згладжування 


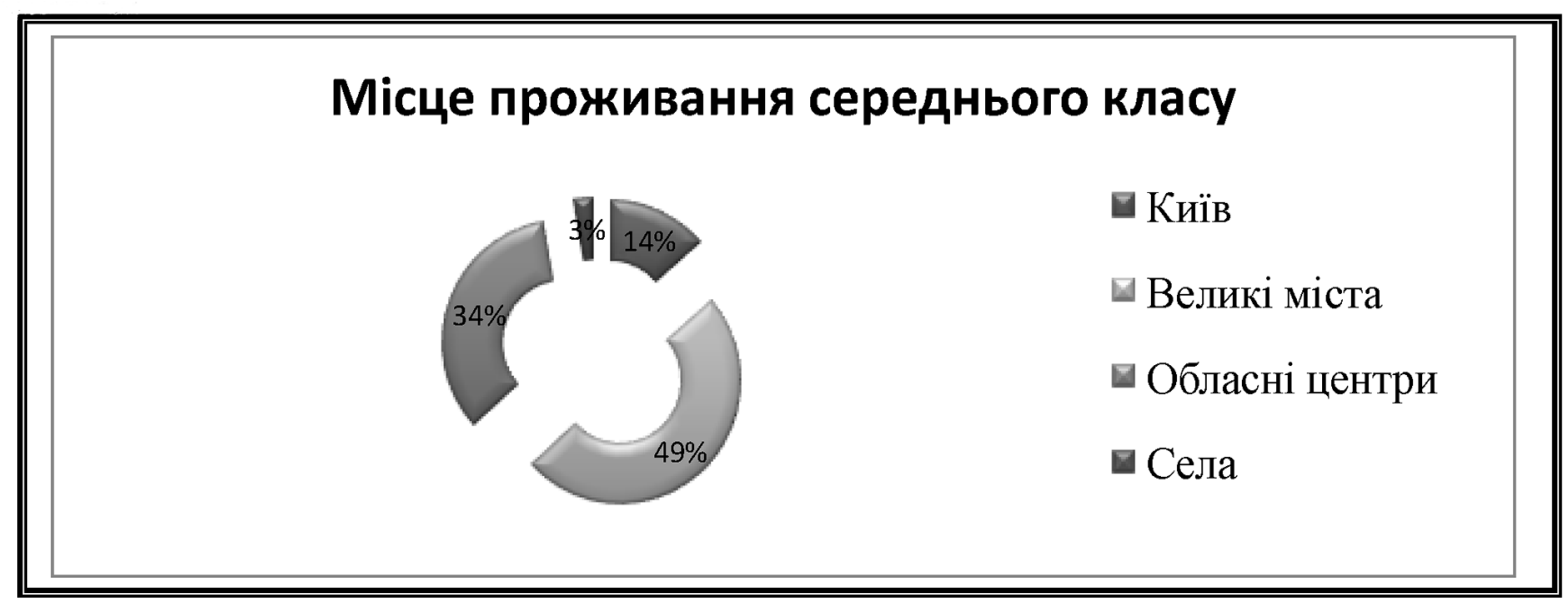

Рис. 1. Розподіл населення України, за місцем проживання середнього класу, 2013 р. (\%) Джерело Дослідження соціологічної служби Українського изентру економічних і політичних досліджень імені Олександра Разумкова

Напрямки подолання бідності та перешкоди для формування середнього класу

\begin{tabular}{|c|c|}
\hline $\begin{array}{c}\text { Головними напрямами державної } \\
\text { політики для зменшення бідності в } \\
\text { Україні: }\end{array}$ & $\begin{array}{c}\text { Основними перешкодами для } \\
\text { формування середнього класу в Україні: }\end{array}$ \\
\hline збільшення ВВПІ на душу населення & $\begin{array}{c}\text { низькі доходи населення та економічна } \\
\text { нерівність }\end{array}$ \\
\hline $\begin{array}{c}\text { індексація заробітної плати в разі } \\
\text { затримкн виплат та підвищення цін }\end{array}$ & $\begin{array}{c}\text { відсутність будь-яких інвестицій, що } \\
\text { забезпечуватимуть спожнвання }\end{array}$ \\
\hline $\begin{array}{c}\text { ефектнвна регіональна політика щодо } \\
\text { внкорінення регіональної бідності }\end{array}$ & $\begin{array}{l}\text { недосконалість дієвих механізмів } \\
\text { стимулювання інвестицій в освіту, житло }\end{array}$ \\
\hline $\begin{array}{c}\text { поліпшення умов для підприємницької } \\
\text { діяльності }\end{array}$ & $\begin{array}{c}\text { відсутність інструментів для регулювання } \\
\text { та стимулювання спожнвання товарів } \\
\text { національного внробництва }\end{array}$ \\
\hline $\begin{array}{c}\text { розробка та впровахження механізмів для } \\
\text { створення новнх робочнх місць }\end{array}$ & $\begin{array}{c}\text { відсутність стимулів для збільшення } \\
\text { акціонерного капігалу, також товарних та } \\
\text { фінансовнх потоків }\end{array}$ \\
\hline
\end{tabular}

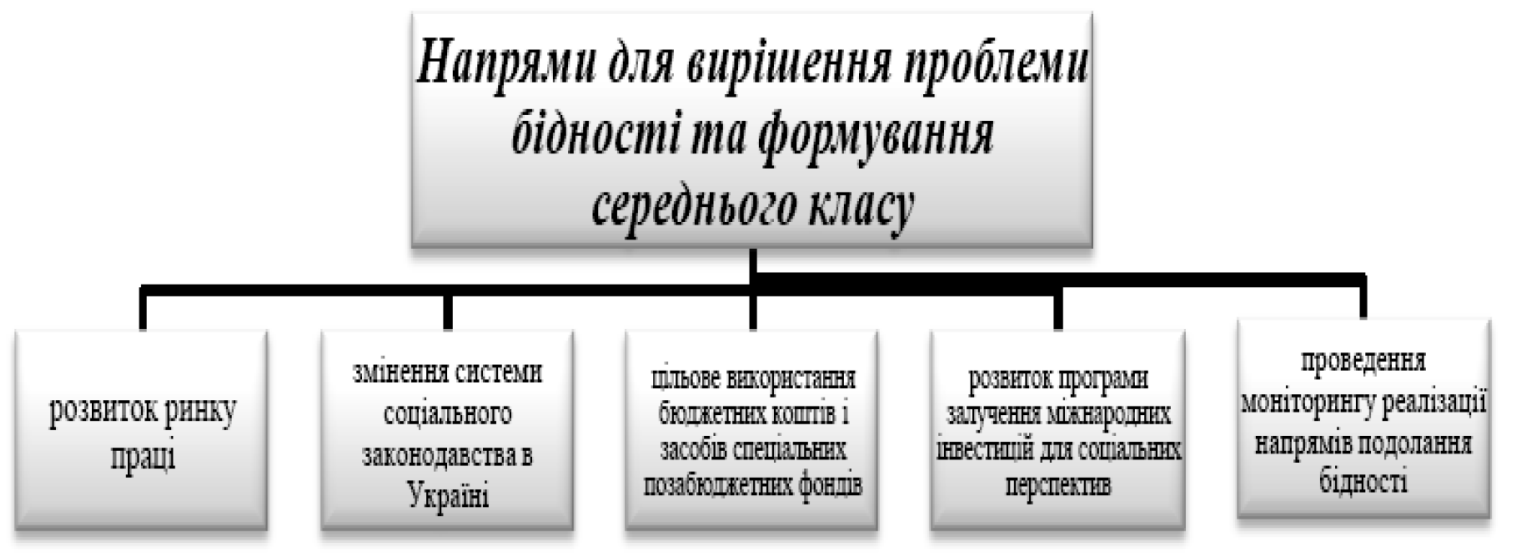

Рис. 2. Напрями вирішення проблеми бідності та формування середнього класу [11] 
дисбалансу у регіональному розвитку за рахунок більш стрімкого розвитку слабких регіонів, що стане початком для викорінення бідності та зростання рівня доходів населення. Реалізація зазначених рекомендацій дозволитьпідвищитирівень доходів українцівіусунути такі соціально-економічні проблеми як бідність, надмірна диференціація населення за доходами, розбалансованість у регіональному розвитку. Дані проблеми потребують подальшого наукового аналізу, a також розробки i впровадження на цій основі надійних механізмів їх реалізації. Для впровадження механізмів подолання бідності необхідно враховувати регіональну, національну, культурну та соціальну парадигму, котра безпосередньо здійснює вплив на вибір тієї чи іншої стратегії подолання бідності. Тому говорити про однозначність та універсальність засобів подолання бідності буде нелогічно, бо потрібно враховувати специфіку кожного регіону. Держава повинна привести своє законодавство у відповідність до законодавства країн ЄС, задіяти економічні важелі стосовно виходу доходів із тіні, ліквідувати корупцію та здійснювати заходи для викорінення бідності в регіонах України, що стануть основою для розвитку середнього класу.

\section{References:}

1. Afanas'êva L., Peresun'ko M. et al. Bidnist'v Ukraïnì : mižnarodnij ta regìonal'nij vimìr. Materiali zasidannâ kruglogo stolu «Realï ta perspektivi podolannâ bidnostì v Ukraïni» [Poverty in Ukraine: international and regional dimension. Materials of the round table "Overcoming poverty in Ukraine: realities and prospects”]. Kyiv, 2010,35 p. (In Ukrainian).

2. Anker R. Čerta bednosti v stranah mira: novaâ metodologiâ i sopostavimye ocenki [The poverty line in the countries of the world: a new methodology and comparable assessments]. Meždunarodnyj obzor truda [International labour review], Moscow, 2008, Vol. 144, No. 4. (In Russian).

3. Bodler Ì., Bugaênko Ê., Ârošenko G. Serednìj klas ì rìven' dohodìv [The middle class and income level]. Pracâ i zarplata [Labor and Salary], 2004, No. 16. (In Ukrainian).

4. Borec'ka N., Sozìnov O. Prìoritetnì naprâmi strategiï rozvitku seredn'ogo klasu u sučasnih umovah [Priority directions of middle class development strategy in modern conditions]. Ukraïna: aspekti praci [Ukraine: aspects of labour], 2010, No. 3, pp. 46-51. (In Ukrainian).

5. Danilišin B. M. (ed.), Černûk L. G., Faŝevs'kij M. İ. Social’no-ekonomičnì problemi regìonìv: metodologiâ ì praktika [Socio-economic problems of regions: methodology and practice]. Cherkasy, 2013, 169 p. (In Ukrainian).

6. İ̂suk S. İ., Gaêvs'ka N. S., Mel'nik Ì. G. Bìdnìst' âk socìal'no-ekonomì̌na kategoriâ j ob'êkt doslìdžennâ suspil'noï geografiï [Poverty as a socio-economic category and the object of human-geographical study]. Ekonomična ta social'na geografîa [Economic and social geography], 2011, Vol. 62, pp. 56-64. (In Ukrainian).

7. Libanova E. Serednìj klas v Ukraïnì: sučasnì masštabi ì problemi rozvitku [The middle class in Ukraine: current scope and problems of development]. Ukraïna: aspekti pracì [Ukraine: aspects of labour], 2002, No. 8. (In Ukrainian).

8. Mezenceva N. İ., Gnatûk O. M., Andrîânova V. M., Moroz V. O. Suspìl'no-geografičnì doslìdžennâ formuvannâ seredn'ogo klasu v Ukraïnì [Human-geographical study of the middle class formation in Ukraine]. Ekonomična ta social'na geografîa [Economic and social geography], 2011, Vol. 62, pp. 169-177. (In Ukrainian).

9. Novikova T. V. Bidnist'v Ukraïni [Poverty in Ukraine]. Access mode: http://cpr.org.ua/?pr=\&\&id+413. (In Ukrainian).

10. Postanova Kabìnetu Minìstrìv Ukraïni «Pro zatverdžennâ Deržavnoï cìl'ovoï socìal'noï programi podolannâ ta zapobigannâ bidnostì na period do 2015 roku» vìd 31 serpnâ 2011 roku \# 1057 [The Order of the Cabinet of Ministers of Ukraine "On approval of the State targeted social programme for overcoming and preventing poverty for the period untill 2015" \# 1057 dated 31 August 2011]. Access mode: http://zakon2.rada.gov.ua/laws/show/1057-2011. (In Ukrainian).

11. Sìtnìkova N. P. Realï ta šlâhi podolannâ bìdnostì v Ukraïnì [Overcoming poverty in Ukraine: realities and directions]. Ekonomika Ukrä̈ni: ìnvesticìjno-ìnnovacìjnìproblemi rozvitku. Kolektivnamonografiâ [Ukrainian economy: investment and innovative development problems. Collective monograph] (Ed.: V. F. Besedìn, A. S. Muzičenko). Kyiv, 2012, pp. 123-131. (In Ukrainian).

12. Statističnij soričnik Ukraïni za 2013 rik: Vitrati ì resursi domogospodarstv Ukrä̈ni (za danimi vibìrkovogo obstežennâ umov žittâ domogospodarstv) [Statistical Yearbook of Ukraine 2013: expenditure and resources of households in Ukraine (according to a sample survey of household living conditions)]. Kyiv, State Statistics Service of Ukraine, 2014, 145 p. (In Ukrainian).

13. The State Statistics Service of Ukraine. Official site. Access mode: http://ukrstat.gov.ua

14. Ukaz Prezidenta Ukraïni «Pro Strategîu podolannâ bidnostì vìd 15 serpnâ 2001 roku \# 637/2001 [Decree of the President of Ukraine «On the Strategy of poverty overcoming» \# 637/2001 dated 15 August 2001]. Kyiv, 2001, 7 p. (In Ukrainian).

15. Vasil'čenko V., Ŝetinìna L. Osnovnì problemi formuvannâ seredn'ogo klasu v Ukraïnì [The main problems of middle class formation in Ukraine]. Ukraïna: aspekti praci [Ukraine: aspects of labour], 2006, No. 3, pp. 31-35. (In Ukrainian). 